
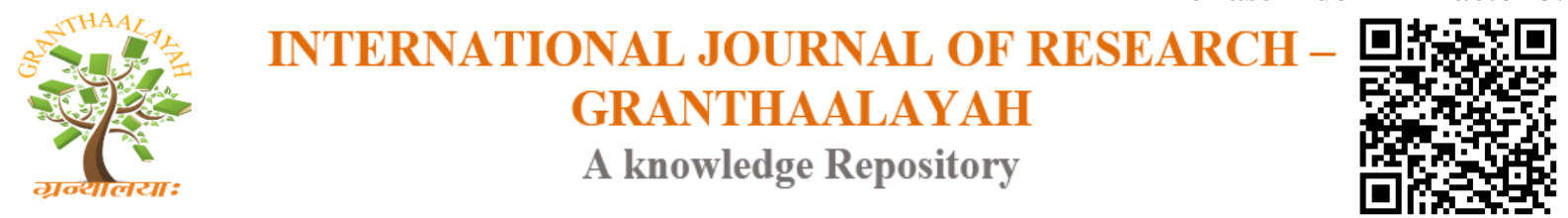

Management

\title{
REGRESSION AND CORRELATION ANALYSIS STOCK PRICE WITH BANKRUPTCY (CASE STUDY WITH ZMIJEWSKI BANKRUPTCY MODEL)
}

\author{
Teguh Sugiarto ${ }^{1}$, Sri Rahayu ${ }^{2}$, Ahmad Subagyo ${ }^{3}$, Ludiro Madu ${ }^{4}$, Amir Mohamadian \\ Amiri ${ }^{5}$ \\ ${ }^{1}$ Doctoral Student Univ. Brawijaya and lecture Univ.Budi luhur and AAJ Jayabaya \\ Jakarta, Indonesia \\ ${ }^{2}$ Doctoral Student at Doctoral Program in Economics, Faculty of Economics and Business, \\ Diponegoro University, Semarang \\ ${ }^{3}$ Lecture GICI Business School, Depok, Jawa Barat, Indonesia \\ ${ }^{4}$ Dept. of International Relations, UPN "Veteran" Yogyakarta, Indonesia \\ ${ }^{5}$ Dwight Way, Berkeley, CA 94720, UC Berkeley, Safe Transportation Research
}

\& Education Center

DOI: https://doi.org/10.29121/granthaalayah.v5.i5.2017.1838

\begin{abstract}
The purpose of this study to determine how the correlation effect of corporate bankruptcies with stock prices. The study was conducted on companies in the ceramics, glass and porcelain sectors whose shares are traded on the Indonesia Stock Exchange and publish the financial statements in Indonesia Stock Exchange (BEI) in the period 2010-2014. The method used in this research is correlation and regression of OLS. From the research that has been done can be concluded that, the result of regression test of five models at the proposed quadratic value of $\mathrm{R}$ is very low and indicate the happening of spurious regression. Using hyposis made concluded that Model H0: $\beta \mathrm{i}$ $=0$ regression is not significant, whereas correlation test on proposal received $\mathrm{H} 0: \beta \mathrm{i} \neq 0$ happened weak correlation between bankruptcy analysis with stock price.
\end{abstract}

Keywords: Analysis of Bankruptcy; Model Zmijewski; Share Price; The Company Ceramics.

Cite This Article: Teguh Sugiarto, Sri Rahayu, Ahmad Subagyo, Ludiro Madu, and Amir Mohamadian Amiri. (2017). "REGRESSION AND CORRELATION ANALYSIS STOCK PRICE WITH BANKRUPTCY (CASE STUDY WITH ZMIJEWSKI BANKRUPTCY MODEL)." International Journal of Research - Granthaalayah, 5(5), 68-72. https://doi.org/10.29121/granthaalayah.v5.i5.2017.1838. 


\section{Introduction}

The company's performance is information that can be used by investors or prospective investors in the capital market to decide the investment. In making investment decisions of market participants or investors can calculate the ratio of each financial statements published by the company. Bankruptcy is a condition in which the companies no longer afford to operate the company well because of the financial difficulties experienced very severe. In this study will be used bankruptcy theory commonly used is Zmijewski Model.

This case study took a sample of companies ceramics, glass and porcelain. Companies selected are companies that continuously deliver or publish financial statements and its shares are traded on the Indonesia Stock Exchange (BEI) in the period 2010-2014. Under these conditions, the study titled: Regression and Correlation Analysis Stock Price With Bankruptcy (Case Study With Zmijewski Bankruptcy Model)

\section{Literature Review}

\section{Zmijewski Model}

The formula conducted by Zmijewski in 1983. By adding some validity financial ratios as detection tools bankruptcy of the company, then Zmijewski develop the model becomes:

X-score $=-4.3$ and Source: R Rulick Setyahadi (2012: 27).

Where: X-Score

$=$ Overal Index or Score,

= Earnings After Tax / Total Assets,

$=$ Total Debt $/$ Total Assets

$=$ Current Assets / Current Liabilities

Zmijewski (1984) stating that the company would face bankruptcy if the probability is if it is greater than 0.5 , in other words, its value $\mathrm{X}$ is 0 therefore, the cut off values that apply in this model is 0 . This means that a company that values $X$ is larger than or equal to 0 is predicted to experience bankruptcy in the future. Conversely, a company that has a value of $\mathrm{X}$ is less than 0 is predicted not to be bankrupt.

\section{Research Hypothesis}

Model $1 \& 2 \& 3 \& 4 \& 5 \mathrm{H} 0: \beta i=0$ occurred regression is not significant and $\mathrm{H} 1: \beta \mathrm{i}=0$ occurred a significant regression.

Model $6 \mathrm{H0}: \beta \mathrm{i} \neq 0$ occurs weak correlation between the analysis of bankruptcy with stock prices and $\mathrm{H} 1: \beta \mathrm{i} \neq 0$ occurs a strong correlation between the analysis of bankruptcy with stock prices. 


\section{Research Methods}

In this study, a public sector company selected ceramics, glass and porcelain listed on the Indonesia Stock Exchange in Jakarta.

\section{Time, Object and Data Research}

The research was done on time in January 2017. The data used in this study is secondary data. Secondary obtained from the Indonesia Stock Exchange period 2010 to 2014, and published on the Website Indonesia Stock Exchange through www.idx.co. id. Which became the object of the research is as follows: PT. Asahimas Flat Glass Tbk, PT. Arwana Citra Mulia Tbk, PT. Ceramic core Alamasri Industry Tbk, PT. Keramika Indonesia Tbk Association, PT.Mulia Industrindo Tbk, PT. Surya Toto Indonesia Tbk

\section{Analysis Method}

In this study, the analysis model used is as follows:

Model $1=Y(\mathrm{hrg} \mathrm{shm})_{t 2010}=\beta_{0}+\beta_{1} X 1(\text { EAT/TA })_{2010}+\beta_{2} X 2(\mathrm{TD} / \mathrm{TA})_{2010}+\beta_{3} X 3(\mathrm{CA} / \mathrm{CL})_{2010}+\varepsilon_{t}$ Model $2=Y(\text { hrg shm })_{t 2011}=\beta_{0}+\beta_{1} X 1(\text { EAT/TA })_{2011}+\beta_{2} X 2(T D / T A)_{2011}+\beta_{3} X 3(C A / C L)_{2011}+\varepsilon_{t}$ Model 3 $=Y(\text { hrg shm })_{t 2012}=\beta_{0}+\beta_{1} X 1(\text { EAT/TA })_{2012}+\beta_{2} X 2(T D / T A)_{2012}+\beta_{3} X 3(C A / C L)_{2012}+\varepsilon_{t}$ Model 4 $=Y(\mathrm{hrg} \text { shm })_{t 2013}=\beta_{0}+\beta_{1} X 1(\text { EAT/TA })_{2013}+\beta_{2} X 2(T D / T A)_{2013}+\beta_{3} X 3(C A / C L)_{2013}+\varepsilon_{t}$ Model $5=Y(\text { hrg shm })_{t 2014}=\beta_{0}+\beta_{1} X 1(\text { EAT/TA })_{2014}+\beta_{2} X 2(T D / T A)_{2014}+\beta_{3} X 3(C A / C L)_{2014}+\varepsilon_{t}$

\section{Results and Discussion}

From the model Hypothesis 1 to 5 which is made on the effect of stock prices to corporate bankruptcy began in 2010-2014. To test this hypothesis, a regression model that is in use there are 5 models of regression analysis. To fit the regression model hypothesis testing, OLS has been used. OLS the regression refers to a method in which aided software statistical software to tell which way the independent variable and where the dependent variable. From the results of the final output, the most significant variable is not significant and will be presented in the regression model is valid, which became the basis for decision-making related to the relationship between the dependent and independent variables of the hypotheses made. The results of this regression model are shown in Table 1.

Table 1: Results of regression analysis models bankruptcy and stock prices

\begin{tabular}{|c|c|c|c|c|c|c|}
\hline Year & $\begin{array}{c}\text { Akaike info } \\
\text { criterion }\end{array}$ & Prob. & t-statistic & Durbin watson & R-squared & F.statistic \\
\hline $\mathbf{2 0 1 0}$ & 22.97506 & No significant & $\begin{array}{c}\text { X2, X3 (Sig.) } \\
\text { C,Xl (no sig.) }\end{array}$ & 1.223558 & 0.270230 & 0.246863 \\
\hline $\mathbf{2 0 1 1}$ & 23.43609 & No significant & $\begin{array}{c}\text { X2, X3 (Sig.) } \\
\text { C,Xl (no sig.) }\end{array}$ & 1.566808 & 0.298917 & 0.284244 \\
\hline $\mathbf{2 0 1 2}$ & 19.92985 & No significant & $\begin{array}{c}\text { X2, X3 (Sig.) } \\
\text { C,Xl (no sig.) }\end{array}$ & 2.376282 & 0.374255 & 0.398730 \\
\hline $\mathbf{2 0 1 3}$ & 20.05387 & No significant & $\begin{array}{c}\text { X2, X3,X3 (no } \\
\text { Sig.) C (sig.) }\end{array}$ & 2.212859 & 0.273136 & 0.250516 \\
\hline $\mathbf{2 0 1 4}$ & 19.27051 & No significant & $\begin{array}{c}\text { X2, X3,X3 (no } \\
\text { Sig.) C (sig.) }\end{array}$ & 2.335634 & 0.570699 & 0.886244 \\
\hline
\end{tabular}

Sources: Proceed by author 
After the model proposed in the show, it was found that five regression models were proposed, there was no statistically significant and valid. It can be seen from the results of the statistical output in the present, where the probability nothing significant, for the value of $t$ test statistics are also only part of significant variable. Likewise, the results of R squared is generated for 5 models

proposed, its value is very low and indicate the occurrence of regression lancing. So as to hypothesize that created concluded receive

Model $\mathrm{H} 0: \beta \mathrm{i}=0$ regression is not significant and rejects $\mathrm{H} 1: \beta \mathrm{i} \neq 0$ regression model is significant.

In probability theory and statistics, correlation, also called correlation coefficient, is a value that indicates the strength and direction of the linear relationship between two random variables (random variable).

Table 2: Figures correlation of each of the correlation coefficient

Coeficient Correlation

$\begin{array}{cccccccccc}\begin{array}{c}\text { High } \\ \text { correlation }\end{array} & \text { High Low } & \text { Low } & \begin{array}{c}\text { No } \\ \text { correlation }\end{array} & \begin{array}{c}\text { No correlation } \\ \text { (random) }\end{array} & \text { Low } & \text { Moderate Moderate High } & \begin{array}{c}\text { High } \\ \text { correlation }\end{array} \\ -1 & < & > & < & >-0.4 & 0 & <= & >+0.4 & <+0.9 & > \\ +0.9 & +1\end{array}$

Sources : Wikipedia Correlation

In this study the correlation analysis model is proposed, as much as the regression analysis model. 5 models in the proposed adjusted with many years in analysis, to explain the relationship between variables in the form of time series data. Here are the results of analysis ranging from table to table 3 to 7.

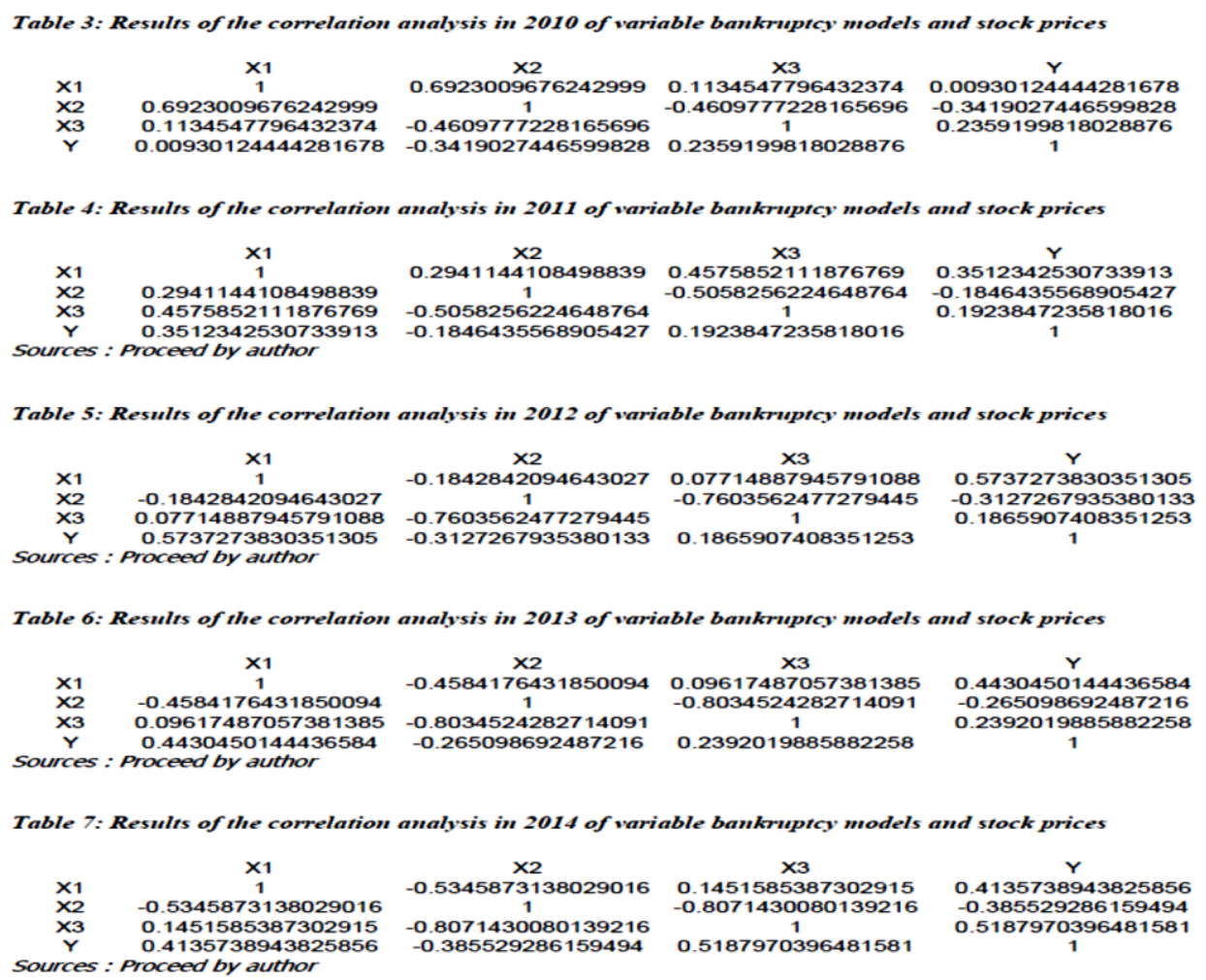


From table 3 to table 7 that are presented above, it appears the numbers generated for the relationship between variable $\mathrm{Y}$ and $\mathrm{X}$ ranges between low and medium value. So it can be concluded for the hypothesis that in a receiving $\mathrm{H} 0: \beta i \neq 0$ occurs weak correlation between the analysis of stock prices and the bankruptcy by rejecting $\mathrm{H} 1: \beta \mathrm{i} \neq 0$ occurs a strong correlation between the analysis of bankruptcy with a stock price for 6 models.

\section{Conclusion}

This study examines the relationship between stock prices with corporate bankruptcy using OLS regression and correlation. From regression test results from five models, in the quadratic value of $\mathrm{R}$ is very low, so it can cause a false regression. Based on the hypothesis made, it can be concluded that Model $\mathrm{H} 0: \beta \mathrm{i}=0$ regression is not significant and reject $\mathrm{H} 1: \beta \mathrm{i} \neq 0$ significant regression model. The correlation test results for five models are created, time series data with jipotesa $\mathrm{H} 0$ : $\beta \mathrm{i} \neq 0$ is received, with a weak correlation between corporate bankruptcy and stock price, and reject $\mathrm{H} 1: \beta \mathrm{i} \neq 0$ there is a strong correlation between bankruptcy With stock prices, Specifically in the proposal for model 6 . This study also does not provide the same opinion about previous research conducted by Imam tri wibowo 2015, where the final results showed that stock prices affect some variables in the Analysis bankruptcy

\section{References}

[1] Algifari. 2010. Statistika Deskriptif Plus untuk Ekonomi dan Bisnis. Ed 1. UPP Sekolah Tinggi Ekonomi Manajemen YKPN. Yogyakarta.

[2] Hansen-Mowen. 2007. Managerial Accounting, Thomson Corporation USA Hilton W Ronald. 2009. Managerial Accounting. Mc Graw Hill (diterjemahkan oleh Salemba Empat. Jakarta)

[3] Prihadi, Toto 2013. Analisa Laporan Keuangan Teori dan Aplikasi. Jakarta: PPM.

[4] Ross, A Stephen cs alih bahasa Ali Akbar Yulianto cs. 2009. Pengantar Keuangan Perusahaan Corporate Finance Fundamentals. Edisi 8. Salemba Empat Jakarta

[5] Sugiyono. 2010. Metode Penelitian Bisnis (Pendekatan Kuantitatif Kualitatif dan R\&D). Alfabeta. Bandung

[6] William cs. 2012. Financial \& Managerial Accounting. Sixteenth Edition. Mc Graw Hill International Edition.

[7] www.yahoofinance.com

[8] www.idx.co.id

[9] www.bei5000.com

[10] www.duniainvestasi.com

[11] www.google.com

[12] https://id.wikipedia.org/wiki/Korelasi

*Corresponding author.

E-mail address: teguh_cpconsulting@yahoo.com 